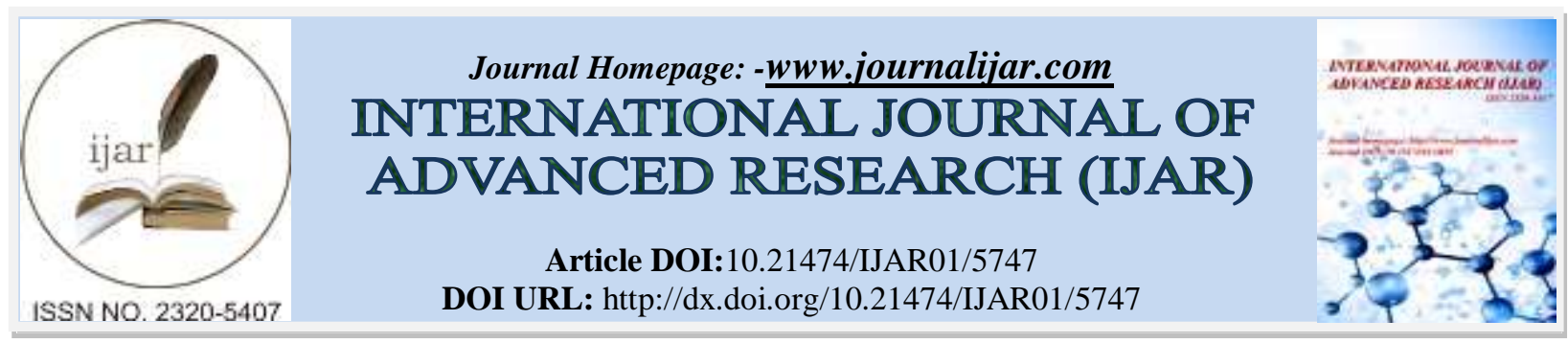

RESEARCH ARTICLE

\title{
DNA EXTRACTION AND PCR DIAGNOSIS OF BREAST CANCER PATIENTS AMONG THE POPULATION OF TRIPURA.
}

\footnotetext{
*Asis Debbarma ${ }^{1}$, Pradip Kumar Ghosh ${ }^{2}$, Subhojit Das ${ }^{1}$, Anubha Nandi Kar ${ }^{3}$ and Biswajit Chowdhury ${ }^{3}$.

1. Assistant Professor, Department of Biochemistry, Agartala Govt. Medical College, Agartala, Tripura West, India.

2. Associate Professor, Department of Biochemistry, Agartala Govt. Medical College, Agartala, Tripura West, India.

3. Junior Research Fellow, DBT Project, Department of Biochemistry, Agartala Govt. Medical College, Agartala, Tripura West, India.
}

\section{Manuscript Info}

n.........................

Manuscript History

Received: 02 September 2017

Final Accepted: 04 October 2017

Published: November 2017

Key words:-

BRCA1, BRCA2, Breast Cancer,PCR.

\section{Abstract:}

Breast cancer is a malignant tumor that starts in the cells of breast. A malignant tumor is a group of cancer cells that can grow into (invade) surrounding tissues or spread to distant areas (metastasize) of the body. Several environmental risk factors that may contribute to or hasten the development of breast cancer have been identified including mainly lifestyle, reproductive factors and family history. Mutations in the $B R C A 1$ and $B R C A 2$ genes profoundly increase the risk of developing breast cancer among women. BRCAl gene is located on chromosome No. 17. The normal BRCA1 genes encode 1863 amino acids. BRCA2 gene located on chromosome No. 13 is another DNA repair gene. The normal BRCA2 genes encode 3418 amino acids. To explore the contribution of BRCAI and BRCA2 mutations in the development of breast cancer among Indian women, we carried out DNA extraction \& PCR analysis of the BRCA1 and BRCA2 genes in thirty eight (38) number of breast cancer female patients from Tripura, India.

Copy Right, IJAR, 2017,. All rights reserved.

\section{Introduction:-}

Genetic predisposition for familial early-onset breast cancer accounts for approximately 5-10\% of all breast cancers and $7-10 \%$ of all ovarian cancers [1]. Mutations in two autosomal dominant genes BRCA1 and BRCA2 have been linked to familial breast or breast and ovarian cancer [2-4]. Women who carry BRCA1 or BRCA2 genes mutations have an estimated lifetime risk of between $60 \%$ and $85 \%$ for developing breast cancer and a lifetime risk of between $26 \%$ and $54 \%$ for developing ovarian cancer for BRCA1, and between $10 \%$ and $23 \%$ for BRCA2 [5-8]. Every year 75,000 new cases of breast cancer are diagnosed in Indian women [9]. In India, breast cancer accounts for about 19$34 \%$ of all cancer cases among women. As per national and regional cancer registries, it is the commonest cancer amongst women in Delhi, Mumbai, Ahmedabad, Kolkata and Trivandrum [10-12]. A recent study on breast cancer risk in India, revealed that one in twenty eight women develop breast cancer during her life time. This is higher in urban areas. In Tripura state too breast cancer is the second leading site among females, the first and third being carcinoma cervix and lungs [13]. Because of the continuing rise in breast cancer incidence, an urgent need to develop strategies for prevention is very much required. Carcinoma of breast has a complex etiology some of which are hormonal, genetic and environmental factors operating over a long period [14]. 


\section{Materials \& Methods:-}

This study was carried out in the DBT Health Care Laboratory, Department of Biochemistry, Agartala Government Medical College in collaboration with Pathology Department, Agartala Government Medical College \& Regional Cancer Center, Agartala during the year March 2016 to September 2017.

\section{Collection of Samples:}

A total fifty eight (58) number of cases were collected from Department of Pathology, Agartala Government Medical College \& Regional Cancer Center, Agartala. Among fifty eight (58) no. of total cases thirty eight (38) cases were positive of breast cancer and twenty (20) no. of cases were using as a control. The age range of the patient was between 22 to 45 years. Five $\mathrm{ml}$ of peripheral blood sample were collected for the proposed test using EDTA vials and stored at $4^{\circ} \mathrm{C}$ till further use if not done immediately.

\section{Histopathology:}

Histopathological study was done for confirmation of the breast cancer. At first, tissue samples were excised by microtome machine $(3-5 \mu \mathrm{m})$. Then the tissue samples were placed on poly L Lysine coating slides. Thereafter Dewaxing or Deparaffinization by Xylene was done which was further rehydrated by $100 \%-70 \%$ - 50\% alcohol, for 5 minutes each. Hematoxyline stain step was done for 1-2 minutes following the $1 \%$ acid alcohol step for differentiation and used 2-4 drops Eosin as a counter stain for 5 minutes.

\section{DNA Extraction from Blood Samples:}

$5 \mathrm{ml}$ of EDTA blood is centrifuged at $1500 \mathrm{rpm}$ for 30 minutes. Serum is partially decanted. To the tube Lysis buffer is added and mixed. Tubes are kept in ice for 30 minutes. Then tubes are centrifuged at $2500 \mathrm{rpm}$ for 20 minutes and supernatant is decanted. $10 \mathrm{ml}$ of Lysis buffer is added then centrifuged at $2500 \mathrm{rpm}$ for 20 minutes and supernatant is decanted. $200 \mu 1$ of $10 \%$ SDS and $500 \mu$ l of Proteinase $\mathrm{K}$ are added to the tubes. Overnight incubated at $37^{\circ} \mathrm{C}$ or 3-4 hours shaking at $56^{\circ} \mathrm{C}$. One $\mathrm{ml} 6 \mathrm{M} \mathrm{NaCl}$ is added and mixed. Tubes are centrifuged at $4000 \mathrm{rpm}$ for 20 minutes. Supernatants are collected in separate tubes. Equal volume of absolute ethanol is added to the supernatant and mixed. $1 \mathrm{ml}$ of $70 \%$ ethanol is added and mixed by inverting the tubes. Tubes are spinned at $6000 \mathrm{rpm}$ and supernatant are discarded carefully. DNA is collected in $1.5 \mathrm{ml}$ microfuge tube.

DNA Purity Test By Spectrophotometer:

The extracted DNA samples by Phenol: Chloroform: Isoamylalcoholmethod was subjected to spectrophotometer as per the standard laboratory procedure. The average DNA purity was obtained- $1.87(260 \mathrm{~nm} / 280 \mathrm{~nm})$ from the extracted DNA samples of 38 breast carcinoma patients by Phenol: Chloroform: Isoamylalcoholmethod.

\section{PCR Analysis:}

BRCA1 \& BRCA2 genes of the extracted genomic DNA will be amplified in PCR by using two sets of primers (BioChain Cat.12210861, BioChain Cat. 12210862), taq polymerase kit supplied by ( QIAGEN Cat nos. 201443 \& 201445) following given steps :-

i) Initial denaturation: at $95^{\circ} \mathrm{C}$ for 2 minutes.

ii) Denaturation: At $95^{\circ} \mathrm{C}$ for 30 seconds.

iii) Annealing: At $60^{\circ} \mathrm{C}$ for 30 seconds.

iv) Extension: At $72^{\circ} \mathrm{C}$ for 1 minute.

v) Final extension: At $72^{\circ} \mathrm{C}$ for 5 minutes

Number of cycles: - 30

\section{Results:-}

A total thirty eight (38) no. of histopathological positive samples belonging to the age range between 22 to 45 years were amplified by PCR. Earlier studies reveal that among the different risk factors of causing breast cancer, age of the individual plays an important role. The age distribution among breast cancer patients are shown in the Table-1.

\begin{tabular}{|l|l|}
\hline Age less than 35 years & Age more than 35 years \\
\hline 25 nos. & 13 nos. \\
\hline
\end{tabular}

Table 1:- Age distribution of breast cancer patients.

In our study, it is revealed that among the 38 positive samples, 25 no. of samples were below 35 years and 13 no. of samples were above 35 years. This suggests that the mutation of BRCA1 and BRCA2 genes are predominant among 
the younger females in compare to older group of female population of Tripura. This is a major concern among the female population of Tripura.

Then, the isolated DNA samples were electrophoresed on 0.8\% agarose gel and shown in Fig-1.

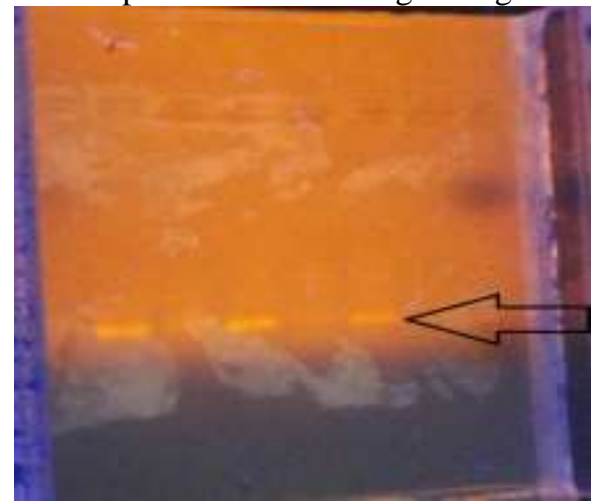

Fig1:- DNA samples on agarose gel $(0.8 \%)$. The arrow indicates the DNA samples. Samples were analysed by spectrophotometer and was followed by PCR amplification.

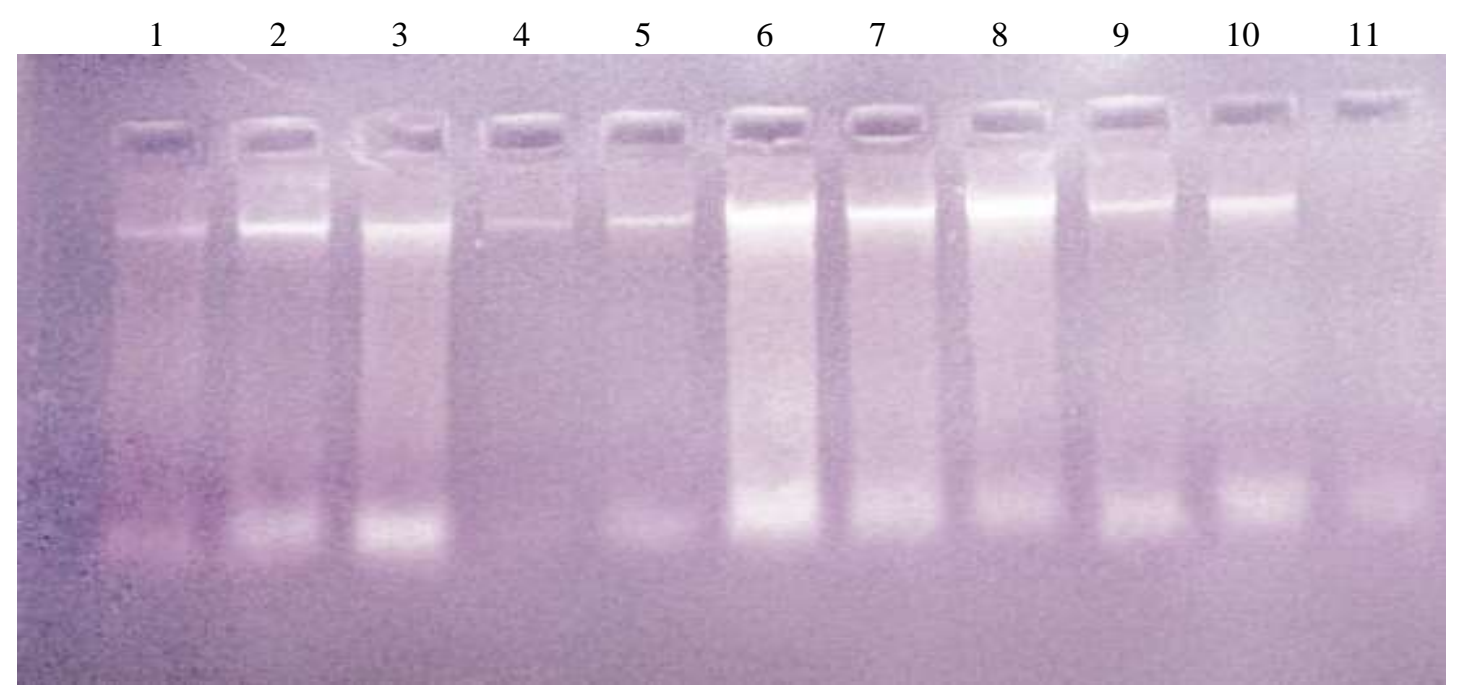

Fig-2:- PCR products on 1.8\% agarose gel.

Then, Electrophoresis was done for the PCR products with $1.8 \%$ agarose gel using Tarsons electrophoresis unit. The amplification of BRCA1 and BRCA2 gene confirmed the diagnosis of breast cancer. DNA amplification by PCR technique using specific primers of breast cancer $(B R C A 1 \& B R C A 2)$ is a widely used technique for diagnosis of breast cancer and one of the reliable techniques in the modern day medicinal field. The amplification of DNA using PCR technique are shown in Fig - 2, including Sl. No.1 to 10 as positive among cases and Sl. No. 11 as negative (control) among cases. The different type of concentrations of DNA represents different type of bands in agarose gel. The results of this study would help to develop to diagnose breast cancer patient and subsequently will provide a milestone in treating the patient with breast cancer among the population.

\section{Discussions:-}

Not many progresses have been made in the past few years in understanding the mutations of $B R C A 1 \& B R C A 2$ gene in breast cancer patients of Tripura population. But it is considered that mutation in the BRCA1 and BRCA2 genes profoundly increase the risk of developing breast and/or ovarian cancer among women. Although their mechanism of action is not yet fully elucidated it is assumed that these genes play a key role in important cellular pathways including response to DNA damage, transcription, and interaction with other proteins involved in DNA repair and apoptosis [15-16]. This study revealed that PCR amplification that was carried out by using specific 
primers (BRCA1 and BRCA2) are shown positive in case of breast cancer and shown negative in control sample (Fig-2). Hence, this positive PCR amplification clearly confirms the diagnosis of breast cancer patients.

Genetic testing helps in identifying high-risk individuals in families with inherited breast cancer, and there are various management options available for mutation carriers. Significant variations in the relative contribution of mutations in BRCA1 and BRCA2 to the development of inherited familial breast and/or ovarian cancer have been reported [17]. Breast cancer is the most frequently diagnosed cancer accounting for $23 \%$ of total cancer cases and $14 \%$ of cancer deaths. The incidence in India is also alarming. Every year about 1.5 lakh new cases of breast cancer have been reported by World Health Organization in India [18].

\section{Conclusion:-}

Thirty Eight (38) number of histpathologically confirmed cases of breast cancer planned for cancer treatment were taken up for study from the Department of Pathology, Agartala Government Medical College \& Regional Cancer Center, Agartala. A total of 20 numbers of female individuals without having any clinical signs \& symptoms of breast cancer were taken as control. We choose the Breast cancer patients in our research work, because the Breast cancer remains the most common cause of death from cancer worldwide including Tripura state. Our goal of being cancer researcher was to extract DNA from blood in order to find out the cause of breast cancer. Here we discussed about the DNA extraction and PCR diagnosis of breast cancer patients by BRCA1 and BRCA2 genes, which plays a major concern among female worldwide.

\section{Acknowledgement:-}

The authors are indebted and thankful to the Department of Biotechnology (DBT), Ministry of Sciences \& Technology, Govt. of India, New Delhi for funding and also for all logistic supports. The authors are also thankful to Department of Pathology, Department of Biochemistry, Agartala Government Medical College and Regional Cancer Center, Agartala for their unconditional support like sample collection etc. for bringing out the work successfully.

\section{References:-}

1. Emery J., Lucassen A. and Murphy M. (2001). Common hereditary cancers and implications for primary care. Lancet., 358:56-63.

2. Hall J.M., Lee M.K., Newman B., Morrow J.E., Anderson L.A., Huey B. and King M.C. (1990): Linkage of early-onset familial breast cancer to chromosome 17. Sci., 250:1684-1689.

3. Miki Y., Swensen J., Shattuck-Eidens D., Futreal P.A., Harshman K., Tavtigian S., Liu Q., Cochran C., Bennett L.M. and Ding W. ( 1994): A strong candidate for the breast and ovarian cancer susceptibility gene BRCA1. Sci., 266: 66-71.

4. Wooster R., Bignell G., Lancaster J., Swift S., Seal S., Mangion J., Collins N., Gregory S., Gumbs C. and Micklem G. (1995): Identification of the breast cancer susceptibility gene BRCA2; Nat. (London)., 378:789792.

5. Easton D.F., Bishop D.T., Ford D. and Crockford G.P. (1993): Genetic linkage analysis in familial breast and ovarian cancer: results from 214 families, The Breast Cancer Linkage Consortium. Am. J. Hum. Genet., 52:678-701.

6. Brose M.S., Rebbeck T.R., Calzone K.A., Stopfer J.E., Nathanson K.L. and Weber B.L.(2002): Cancer risk estimates for BRCA1 mutation carriers identified in a risk evaluation program. J. Natl. Cance.r Inst., 94: 13651372.

7. Antoniou A., Pharoah P.D., Narod S., Risch H.A., Eyfjord J.E., Hopper J.L., Loman N. and Olsson H. (2003) Average risks of breast and ovarian cancer associated with BRCA1 or BRCA2 mutations detected in case Series unselected for family history: a combined analysis of 22 studies. Am. J. Hum. Genet., 72: 1117-1130.

8. King M.C., Marks J.H. and Mandell J.B. (2003): Breast and ovarian cancer risks due to inherited mutations in BRCA1 and BRCA2. Sci., 302: 643-646

9. Chopra R. (2001): The Ind. Sci. J ClinOncol., 19: 106-111.

10. National cancer Registry programme. Ten year consolidated report of the hospital based cancer registries19841993. An assessment of the burden and care of cancer patients, New Delhi: Ind. Council of Med. Res., 2001.

11. National cancer Registry programme. Consolidated report of the population based cancer registries 1990 -1996, New Delhi: Ind. Council of Med. Res., 2001.

12. National cancer Registry programme. Consolidated report of the population based cancer registries 1990- 1996. Supplement: Year wise tabulation of incident cancers and rates by site and gender, New Delhi: 
13. Indian Council of Medical Research; 2001.National cancer Registry programme. Annual report of Population based cancer registry, Tripura State, Ind. Council of Med. Res., 2009.

14. Saxena S., Rekhi B., Bansal A., Bagga A., Chintarani and Murthy N.S., (2005): Clinico-morphological patterns of breast cancer including family history in a New Delhi Hospital, India-Acros sectional study. World. J. Surg. Oncology., 3: 67.

15. Somasundaram K. (2003): Breast cancer gene 1 (BRCA1): role in cell cycle regulation and DNA repairperhaps through transcription. J. Cell. Biochem.,88: 1084-1091.

16. Narod S.A. and Foulkes W.D. (2004): BRCA1 and BRCA2: 1994 and beyond; Nat. Rev. Cancer., 4:665-676.

17. Liebens F.P., Carly B., Pastijn A. and Rozenberg S. (2007): Management of BRCA1/2 associated breast cancer: a systematic qualitative review of the state of knowledge in 2006. Eur. J. Cancer.; 43:238-257.

18. Bhaumik A., Das S., Sarkar S.R., Chakraborty P. and Chowdhury B. (2015): Immunohistochemical Diagnosis of Breast Cancer Cases with Prognostic Markers: ER, PR \& HER2/Neu. Ind. J. Appl. Res., 5: 468-470. 